See discussions, stats, and author profiles for this publication at: https://www.researchgate.net/publication/321058421

\title{
DNA barcode for identification of immature stages of sand flies (Diptera: Psychodidae) collected from natural breeding sites
}

Article in Zootaxa . June 2017

\section{CITATIONS}

2

9 authors, including:

Rafael J. Vivero

University of Antioquia

64 PUBLICATIONS 227 CITATIONS

SEE PROFILE

Fernando Flórez

Servicio Nacional de Aprendizaje SENA

6 PUBLICATIONS 30 CITATIONS

SEE PROFILE
READS

169

uis Gregorio Estrada

Universidad de Sucre

10 Publications 40 Citations

SEE PROFILE

Carolina Torres Gutierrez

Abt Associates, Bethesda, MD.

23 PUBLICATIONS 129 CITATIONS

SEE PROFILE

Some of the authors of this publication are also working on these related projects:

Directed Evolution View project

Morphological and molecular taxonomy, and phylogeny of the subgenus Nyssorhynchus of the genus Anopheles (Diptera: Culicidae), with special emphasis on Anopheles darlingi from Mata Atlântica View project 
https://doi.org/10.11646/zootaxa.4277.2.3

http://zoobank.org/urn:lsid:zoobank.org:pub:A93A7BED-CD99-43C5-8B09-3BEA67C2314E

\title{
DNA barcode for identification of immature stages of sand flies (Diptera: Psychodidae) collected from natural breeding sites
}

\author{
RAFAEL JOSÉ VIVERO ${ }^{1,4}$, EDUAR ELÍAS BEJARANO ${ }^{2}$, LUIS GREGORIO ESTRADA ${ }^{2}$, \\ FERNANDO FLÓREZ ${ }^{2}$, EDGAR ORTEGA-GÓMEZ ${ }^{2}$, YAMILETH APARICIO ${ }^{2}$, \\ CAROLINA TORRES-GUTIÉRREZ1 ${ }^{1}$, SANDRA URIBE-SOTO³ \& CARLOS MUSKUS-LÓPEZ ${ }^{1}$ \\ ${ }^{1}$ Program for Study and Control of Tropical Diseases (PECET), Faculty of Medicine, Universidad de Antioquia, Medellín, Colombia \\ ${ }^{2}$ Biomedical Research Group, Universidad de Sucre, Sincelejo, Colombia \\ ${ }^{3}$ Research Group on Molecular Systematics, Faculty of Science, National University of Colombia (Medellin branch), Medellín, \\ Colombia \\ ${ }^{4}$ Corresponding author
}

\begin{abstract}
Although phlebotomine sand flies breeding sites have been identified and recorded by several studies, the microhabitats exploited by these insects remain little-known and hard to find. In this context, the difficulty of finding immature stages, and the limited number of taxonomic studies to identify immature stages of phlebotomine sand flies, are considered the major obstacles when attempting a complete inventory of Lutzomyia species. The objective of this study is to validate $C y$ tochrome Oxidase I (Barcode region) as a marker for the identification of immature stages of Lutzomyia species recovered from natural breeding sites in Colombia. Among 142 collected sand flies, 18 immature individuals that did not complete their life cycle were identified to species level through sequencing of the COI gene. Values of K2P genetic distance between 0.002-0.031 allowed the identification of larvae at species level. The bootstrap support values (96\%) in the Neighbor-Joining dendrogram were consistent for the majority of the established MOTUS of Lutzomyia atroclavata, Lutzomyia micropyga, Lutzomyia serrana, Lutzomyia cayennensis, Lutzomyia rangeliana, Lutzomyia shannoni and some species of the genus Brumptomyia. The COI gene is validated as a marker for the identification of immature stages of the genus Lutzomyia.
\end{abstract}

Key words: Brumptomyia, Lutzomyia, Colombia, Cytochrome Oxidasel I, mitochondrial DNA

\section{Introduction}

Females of Lutzomyia França are hematophagous insects and some species are capable of transmitting parasites of Leishmania Ross (Kinetoplastida: Trypanosomatidae) (Bates 2015). This fact raises an epidemiological issue for human communities dwelling in tropical regions, where such insects occur in great diversity. In most cases, the available entomological records for Lutzomyia species are based only on adult sampling surveys. Such insect sampling would be improved if the immature specimens are studied as well (Vivero et al. 2015).

The lack of taxonomic information that limits the production of taxonomic keys for the immature stages of Lutzomyia species, as well as the difficulty to find the natural breeding sites (Feliciangeli 2002), are the main barries for the complete and representative inventories of sand flies in a determined area. In the scientific literature, scanning electron microscopy appears to be the most appropriate technique for studying the chorionic structure of eggs of sand flies. With this technique, some authors have contributed with the description of morphological characteristics of eggs and the chaetotaxy of larvae associated to species of medical importance and description of the mouthparts to differentiate some Lutzomyia species (Hanson 1968; Endris et al. 1987; Ward 1976; Feliciangeli et al. 1993; Pérez \& Ogusuku 1997; Fausto et al. 1998; Arrivillaga et al. 1999; Sierra et al. 2000). However, this methodology is considered complex and expensive. Though there are a few contributions on morphological traits of immatures in Lutzomyia (Ward 1976; Arrivillaga et al. 1999), they are considered isolated and exploratory studies (Sierra et al. 2000). 
In an epidemiological context, when an inventory of species is required, a survey should include not only information about the adults but also about immature forms. For example, the systematic control of other insect vectors such as mosquitoes (vectors of malaria and dengue), is often aimed at the larval stages, in aquatic breeding sites, and adult stage (Feliciangeli 2004). However, this strategy has not been possible in the control of sand flies. This premise and the problems previously discussed have motivated new initiatives and methodologies directed toward the study of immature stages of Lutzomyia. In recent years, genes with different substitution rates and types of inheritance, such as mitochondrial (Cytochrome Oxidase I, Cytochrome B, NADH 1 and NADH 4, Serine tRNA) and nuclear (Period, Cacophony, Paralytic), have been used for the differentiation of Lutzomyia species, mainly in adult stage (Vivero et al. 2007; Depaquit 2014; Dvorak et al. 2014; Pinto et al. 2015).

Nevertheless, the usefulness of these genetic markers to identify immature stages of sandflies collected on natural breeding sites has not been evaluated. Currently, there are online platforms such as DDBJ, EMBL-EBI and NCBI, bio-informatics tools such as BLAST, Clustal Omega and several methods, that could be used to perform alignments, and assigning the taxonomic identity, in a rapid manner and with good support and precision at species level (Hebert et al. 2003). The Cytochrome Oxidase I (COI) mitochondrial gene is used as a genetic barcode to assign taxonomic identity to many insects, among them, the medically important insect groups (Contreras et al. 2014; Romero et al. 2016), thus appearing as a potential gene for the identification of immature phlebotomine sand fly stages collected from breeding sites (Romero et al. 2016). The COI gene has also been used for the delimitation of Lutzomyia species in leishmaniasis transmission areas in the Andean and Caribbean regions of Colombia (Contreras et al. 2013; Romero et al. 2016). Other studies have shown the usefulness of COI gene to explore the diversity of sand flies species (Azpurua et al. 2010), and to reconstruct the phylogeny of sandflies in Peru, Colombia and Ecuador (Cohnstaedt et al. 2011; Kato et al. 2015; Nzelu et al. 2015). All these sequences from these studies can be used to compare with sequences of COI gene of immature stages.

Considering the importance of studying the immature stages of phlebotomine sandflies in the context of epidemiology and control of leishmaniasis, the objective of this study is to assign the taxonomical identity to immature stages of sandflies, by using the sequences of the mitochondrial gene COI.

\section{Material and methods}

Study area. We conducted entomological surveys in three Natural Reserves in Colombia: "Río Claro" $\left(5^{\circ} 49^{\prime} 59.37^{\prime \prime} \mathrm{N}, 74^{\circ} 52^{\prime} 00.62^{\prime} \mathrm{W}, 418 \mathrm{~m}\right.$ a.s.l.) located in the municipality of San Francisco (Department of Antioquia), "El Aguacate" (8 $8^{\circ} 36^{\prime} 53.85^{\prime} \mathrm{N}, 7^{\circ} 19^{\prime} 39.15^{\prime} \mathrm{W}, 13 \mathrm{~m}$ a.s.1.) in the municipality of Acandí (Department of Chocó), "Primates" (09 31 '48.0"N, 75²1'4.3"W, $220 \mathrm{~m}$ a.s.l.) in the municipality of Colosó, and in the urban area of the City of Sincelejo ( $9^{\circ} 18^{\prime} 09.75^{\prime \prime} \mathrm{N}, 75^{\circ} 23^{\prime} 42.22^{\prime \prime} \mathrm{W}, 209 \mathrm{~m}$ a.s.l.), located in the Department of Sucre.

Isolation and processing of immature sandflies. A total of 160 possible breeding sites were explored. The isolation of larvae, pupae and exuviae was performed by direct examination. Adults were also collected, with emergence traps and incubation of soil samples of breeding sites in the laboratory (Vivero et al. 2015). The immature stages recovered dead during isolation and laboratory breeding were kept dried in $1.5 \mathrm{~mL}$ vials at $-20^{\circ} \mathrm{C}$ for molecular identification using the COI genetic barcode sequence.

DNA extraction and partial amplification of the Cytochrome Oxidase I gene. The DNA extraction of immature stages of sandflies was performed according to the protocol of high salt concentration (Vivero et al. 2007). In the case of the larvae, the head was separated as a taxonomic support, while the pupae were processed completely. The $5^{\prime}$ fragment of the mitochondrial gene $C O I(680 \mathrm{pb})$ was amplified using the oligonucleotides LCO1490 (5'-GGTCAACAAATCATAAAGATATTGG-3') and HCO2198 (5'TAAACTTCAGGGTGACCAAAAAATCA-3') (Folmer et al. 1994). The amplified products were purified using Wizard PCR Preps (Promega) and sequenced in both senses, in an automatic sequencer ABI 3730XL of capillary electrophoresis.

Molecular analysis of the Cytochrome Oxidase I gene. The obtained chromatograms were edited with BioEdit (Hall 1999) software to generate a partial consensus sequence of the COI gene for each one of the immature specimens. The multiple alignment was performed with Clustal W (Higgins et al. 1992) algorithm incorporated in MEGA 5.05 (Tamura et al. 2011), with a posterior manual edition for the delimitation of the codifying fragment size to be analyzed. The mitochondrial genetic code of invertebrates was used to guarantee the 
correct reading frame of the codons and the identification of variable sites corresponding to nucleotides and aminoacids using the MEGA 5.05 software. To verify the identity of the partial sequences of the $C O I$ gene obtained of immature stages, a previous analysis was performed in BLAST (Altschul et al. 1997) with sequences of adults. At the same time, a sequence matrix for the COI gene corresponding to adults of Lutzomyia, Brumptomyia and Bruchomyiinae was built with the sequences of adults from different regions of Colombia, retrieved from Genbank. The analyzed fragment of the COI gene corresponded to the positions 1567 to 2144 on the mitochondrial genome used as reference (L. umbratilis Ward \& Fraiha; Genbank accession no. KP702938).

The genetic divergences among sequences from immature specimens of sandflies were evaluated with MEGA 5.05 , as well as the nucleotide composition, haplotype variability, variable sites and parsimonious sites. The absence of NUMTs was also verified. The NUMT in these sequences of immature stages, was examined with BLAST to search the regions of similarity with our mitochondrial sequences. Strategies to help identify these alien sequences include search for ambiguity among sequences, noise, or double peaks in the electropherogram; sequence translation in search for additional termination codons and the comparison of the amplified sequences with other published sequences from closely related species. Verification of recombination events and the presence of chimeras was performed with RDP4 (Recombination Detection Program version 4) software, using all sequences of $\mathrm{COI}$ obtained in our study in order to ensure the accuracy of the nucleotide variability with respect to previously reported sequences in GenBank.

With the final alignment of $C O I$ from immature and adult stages with taxonomic identity known, the paired genetic intra/interspecific distances were calculated under the bi-parametrical model of Kimura (K2P) (Kimura 1980), which gives different mutation rates to transitions and transversions. The sequence matrix of $C O I$ gene fragments was exported to MEGA 5.05, to generate a Neighbor-Joining dendrogram (Saitou \& Nei 1987), using the K2P genetic distances, and following the standard recommendations of the Barcode of Life (Hebert et al. 2003; Lanteri 2007; http://www.boldsystems.org/index.php/Resources). The sequences from the partial segment of the COI gene reported for immature stages were submitted to GenBank.

\section{Results}

\section{Genetic analysis of sequences for identification of immature stages}

13 species of Lutzomyia and two of Brumptomyia França \& Parrot genera were identified (Table 1). A total of 18 immature specimens (12.67\%) were identified through analysis of the $680 \mathrm{bp}$ fragment of the COI gene (Table 1). These immature specimens, did not complete their development to adult stage.

The average nucleotide composition of the $C O I$ gene of the immature specimens corresponded to a $67.8 \%$ of Adenine-Thymine relation and a $32.2 \%$ Guanine-Cytosine relation (Table 2), denoting differences in genetic composition with respect to the species. In the 18 sequences of immature sand flies from this study, a total of 14 haplotypes, and a low number of variable sites, were obtained (Table 2). The majority of variable changes were Cytosine by Thymine in the third codon position.

The minimal intra-specific K2P distance was of 0.002 in the Lutzomyia species, except for L. shannoni (Dyar) and L. cayennensis cayennensis (Floch \& Abonnenc) (0.006) (Table 2). The maximal intra-specific K2P distance was 0.031 , detected in specimens of $L$. dubitans and L. rangeliana (Table 2). In Brumptomyia, intra-specific K2P values varyed from 0.002 to 0.033 . This showed consistency for this marker at the taxonomical level, as well as for the identification of the species B. hamata (Fairchild \& Hertig) and B. mesai Sherlock (Table 2). The inter-specific values of K2P distances for the different Lutzomyia species ( $>0.1)$, between Brumptomyia and Lutzomyia (0.1300.194) and upon comparison of Lutzomyia species and specimens from Bruchomyiinae (0.142-0.235), showed higher values which is in agreement with the percentages previously established in the Barcode initiative for interspecific values.

The Neighbor-Joining dendrogram obtained under the K2P model, corroborated the identification of immature stages of Lutzomyia and Brumptomyia in our study (Figure 1). The groups defined as molecular operational taxonomic units (MOTUs) clarify the differentiation between species according to high bootstrap values detected (95-99\%) (Figure 1). 


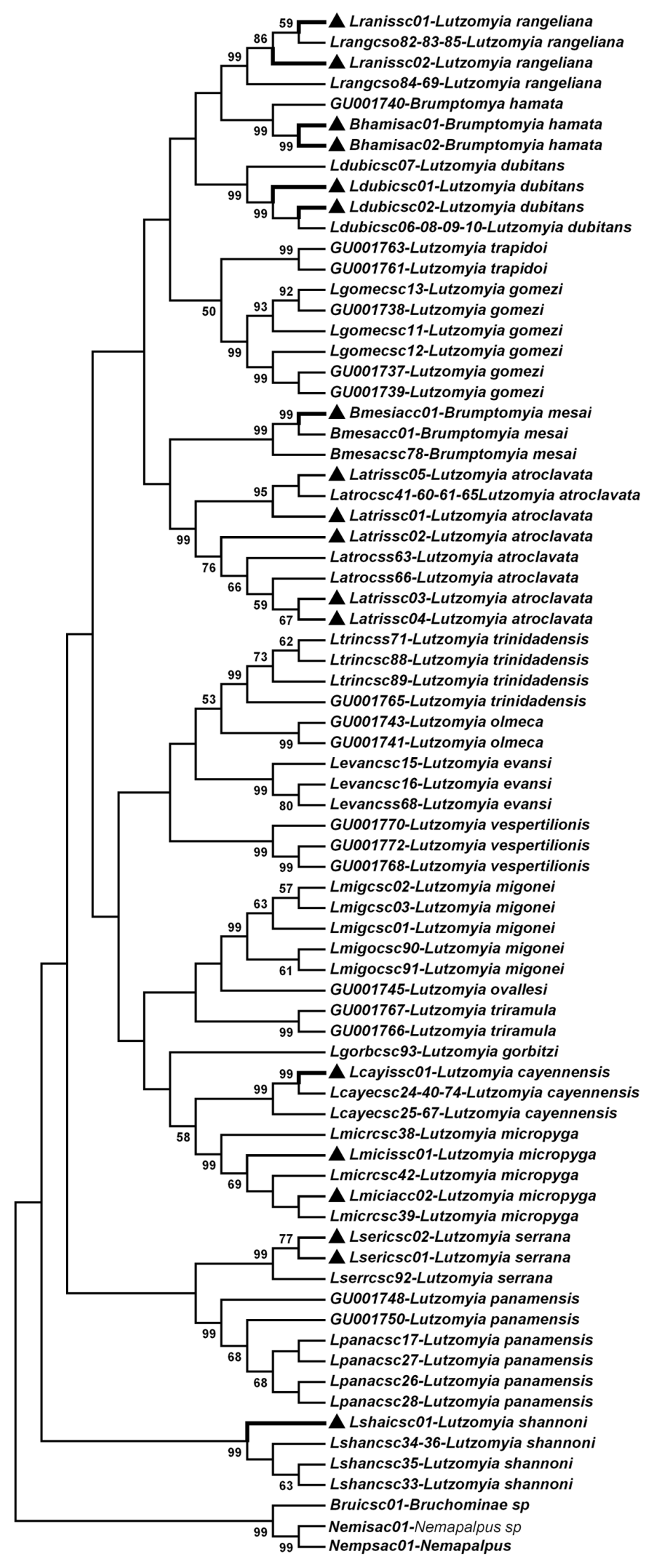

FIGURE 1. Neighbor-joining analysis of mitochondrial COI sequences of immature stages of sand flies isolated from natural breeding sites, contrasted with COI gene sequences from adults from GenBank. The black triangles represent the larvae and pupae identified. 
TABLE 1. Sandfly species isolated from natural breeding sites, identified with the analysis of mitochondrial COI sequences and reared under laboratory conditions.

\begin{tabular}{|c|c|c|c|c|c|c|}
\hline Species & Breeding sites & Study areas & $\begin{array}{l}\text { Number of } \\
\text { emerged adults }\end{array}$ & $\begin{array}{l}\text { Number of } \\
\text { immatures } \\
\text { (DNA } \\
\text { barcode) }\end{array}$ & $\begin{array}{l}\text { Number of } \\
\text { immatures } \\
\text { identified only } \\
\text { to genus }\end{array}$ & Total $(\%)$ \\
\hline L. atroclavata & $\mathrm{Tb}, \mathrm{Tt}, \mathrm{Tc}$ & Sincelejo & 9 & 5 & --- & $14(9.86)$ \\
\hline L. migonei & $\mathrm{Tb}, \mathrm{Tt}, \mathrm{Tr}$ & Primates & 13 & --- & --- & $13(9.15)$ \\
\hline L. micropyga & $\mathrm{Tb}, \mathrm{Ll}, \mathrm{Tc}, \mathrm{Tr}$ & $\begin{array}{l}\text { Sincelejo, Primates, El } \\
\text { Aguacate, Rio Claro }\end{array}$ & 6 & 2 & --- & $8(5.63)$ \\
\hline L. serrana & $\mathrm{Tb}, \mathrm{Th}, \mathrm{Tt}$ & Primates & 3 & 2 & --- & $5(3.52)$ \\
\hline L. dubitans & TM, Th, Cv & Sincelejo, Primates & 4 & 2 & --- & $6(4.23)$ \\
\hline L. evansi & $\mathrm{Tb}, \mathrm{Ll}$ & Sincelejo, Primates & 5 & --- & --- & $5(3.52)$ \\
\hline L.c. cayennensis & $\mathrm{Tb}, \mathrm{Ll}, \mathrm{Tc}$ & Sincelejo, Primates & 6 & 1 & --- & $7(4.93)$ \\
\hline L. rangeliana & $\mathrm{Tb}, \mathrm{Tc}, \mathrm{Tn}$ & Sincelejo & 2 & 2 & --- & $4(2.82)$ \\
\hline L. ovallesi & $\mathrm{Ll}$ & Primates & 2 & --- & --- & $2(1.41)$ \\
\hline L. shannoni & Th & Primates & 1 & 1 & --- & $2(1.41)$ \\
\hline L. trinidadensis & $\operatorname{Tr}$ & Rio Claro & 2 & --- & --- & $2(1.41)$ \\
\hline L. pilosa & $\operatorname{Tr}$ & Rio Claro & 2 & --- & --- & $2(1.41)$ \\
\hline L. gorbitzi & Th & Primates & 1 & --- & --- & $1(0.70)$ \\
\hline B. hamata & $\mathrm{Th}, \operatorname{Tr}$ & El Aguacate, Rio Claro & 4 & 2 & --- & $6(4.23)$ \\
\hline B. mesai & $\operatorname{Tr}$ & El Aguacate & --- & 1 & --- & $1(0.70)$ \\
\hline Subtotal (\%) & --- & --- & $60(42.25)$ & $18(12.67)$ & --- & $78(54.92)$ \\
\hline Lutzomyia spp. & $\begin{array}{l}\text { Tb, Th, Tt, Ll, } \\
\text { Tc, Tm, Tr }\end{array}$ & $\begin{array}{l}\text { Sincelejo, Primates, Rio } \\
\text { Claro }\end{array}$ & --- & --- & 38 & $38(26.76)$ \\
\hline $\begin{array}{l}\text { Brumptomyia } \\
\text { spp. }\end{array}$ & $\operatorname{Tr}$ & El Aguacate & --- & --- & 26 & $26(18.30)$ \\
\hline Total (\%) & & & $60(42.25)$ & $18(12.67)$ & $64(45.07)$ & $142(100)$ \\
\hline
\end{tabular}

Abbreviations for natural breeding sites Tb. Tree-bases; Tt. Trunk of tree; Bk. Tree-cortex; Ll. Leaf litter; Tr. Tabular roots; Th. tree-holes; CV. Cave; TM. Termite-nests.

\section{Discussion}

Taxonomic studies of immature insects are scaroe and complex because knowledge of morphological characters is limited. A particular case is presented in Phlebotominae Rondani, where the absence of taxonomical keys for immature stages symbolizes how partial the available inventories are, including only information of adult stages (Vivero et al. 2013). This study validated in a consistent way, the use of the mitochondrial gene COI as a molecular marker for the identification of immature stages collected from natural breeding sites.

In this sense, the comparative analysis of partial sequences of the COI gene between immature and adult stages of sand flies, and the use of morphology, suggests a high congruency in the taxonomical assignation of Lutzomyia and Brumptomyia species. The use of COI gene for the identification of immature stages of Lutzomyia and Brumptomyia species are supported by the well-differentiated values of intra-specific genetic distance values $(0.2-$ $3.1 \%)$ compared to the inter-specific (12.4-20.1\%) divergence values. The "Barcode Gap" effect is evidenced as an adequate criteria for the genetic variation between species (Hebert et al. 2003), assuming that the lines diversify faster between species than inside of them. This affirmation is coherent with the estimation of a bigger number of synonym substitution (transition) in the COI mitochondrial gene in the third position, upon comparison on taxonomical level (Blouin et al. 1998).

Other argument supporting the use of $C O I$ gene is the absence of stop codons or NUMTs sequences inside the analyzed fragment. Also, the bootstrap support $(99 \%)$ in the Neighbor-Joining dendrogram demonstrated the 


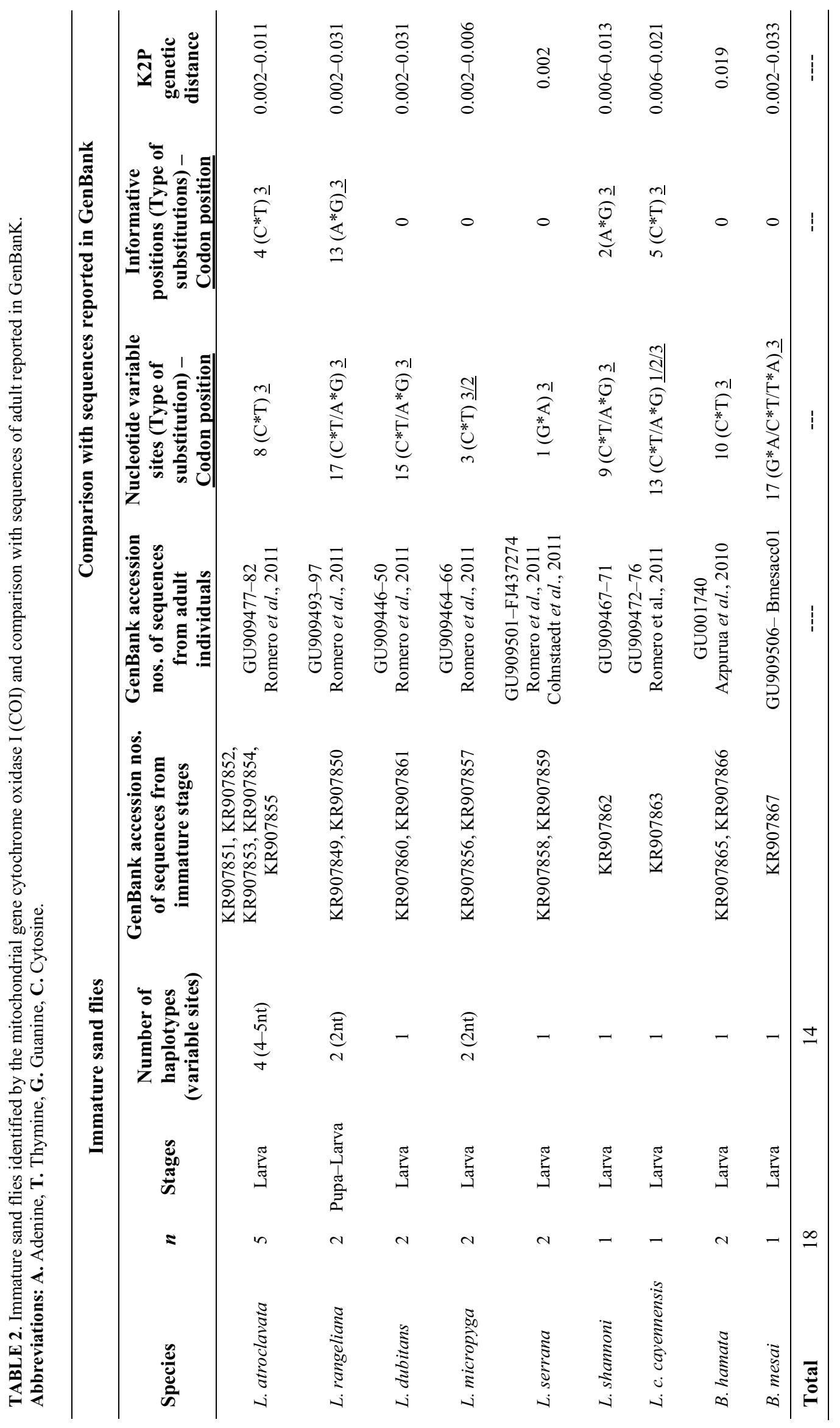


cohesiveness of the groupings (MOTUs) that included $\mathrm{COI}$ sequences from adults and immatures obtained from a wide geographic range including different ecosystems, habitats and micro-habitats.

Getting readable sequences from larvae and pupae collected from different organic substrates with decomposing materials and high concentration of humic acids (Vivero et al. 2013) is complex and need DNA extraction methods that have good performance at low $\mathrm{pH}$ and that may block chelating substances from the organic substrates. These humic acids may interfere with the DNA amplification (Boom et al. 1990). Also, the contents of the gastrointestinal tract of the larvae can include the presence of nematodes, fungi, vegetable material and arthropod rests under decomposing processes that could eventually affect the specificity of the DNA amplification in immature stages of sandflies.

Currently, very little information is available regarding the identification of immature stages of Lutzomyia, using the DNA barcoding in Colombia (Contreras et al. 2013). In the present study, the utility of the COI marker is demonstrated given that a total of 18 specimens were identified, represented by seven species of genus Lutzomyia (L. atroclavata, L. c. cayennensis, $L$. dubitans, L. micropyga, L. rangeliana, L. serrana, L. shannoni,) and two species from genus Brumptomyia (B. hamata, B. mesai).

Despite the scarcity of molecular taxonomical studies for immature stages of sandflies, it is worth noticing that such contributions exist for other arthropods and insect groups, between these: COI sequences comparison to distinguish non identified immature stages of species of Cicuria Menge (Araneae: Dictynidae) (Paquin \& Hedin 2004); identification of morphologically undistinguishable larvae of species of canegrubs (Coleoptera: Scarabaeidae), using traditional techniques as well as DNA sequences (Miller et al. 1999); and the identification of non-described, undistinguishable larvae of Philodytes umbrinus (Motschulsky) (Coleoptera: Dytiscidae), through the comparison of $C O I$ sequences obtained from adults of the same species with known identity (Miller et al. 2005).

The analysis of nucleotide sequences complemented with the morphological patterns (e.g. terminal setae) facilitates the identification of immature stages Lutzomyia and Brumptomyia recovered in natural breeding sites at leishmaniasis transmission areas. The methodological scheme and obtained results set a platform for future identifications of non-identified larvae and the opportunity to apply these procedures for future studies involving morphological and molecular topics. Studies such as the present, are relevant given the lack of knowledge about immature forms of most species of sandflies and the increasing number of studies focused on finding these immatures, some of which remain unidentified because they do not reach adulthood. DNA barcoding use as proposed by us here, appears as an alternative to species determination.

\section{Conclusions}

This study was planned as a complementary identification tool in entomological surveys in order to accelerate the finding of vector species in transmission areas where leishmaniasis is prevalent.. In this sense, the COI gene was validated as a marker for the identification of immature stages of the Lutzomyia recovered from natural breeding sites.

\section{Acknowledgments}

We grateful for the academic and scientific support of the Program for Study and Control of Tropical Diseases (PECET), Faculty of Medicine, Universidad de Antioquia, Medellín, Colombia, the Biomedical Research Group of the University of Sucre and Research Group on Molecular Systematics at the National University of Colombia (Medellin branch). We are also grateful for the help in field sampling of Horacio Cadena, researcher of the Program for Study and Control of Tropical Diseases of the University of Antioquia. Finally, we thank the different communities of the natural reserves visited during our surveys in different Colombian regions (El AguacateCorporación Fragmento, Río Claro, Colosó) for giving us access to their facilities, providing hospitality and collaborating with fieldwork. Sponsorships: Administrative Department of Science, Technology and InnovationCOLCIENCIAS (code \# 695-2014111540820514, code \# 695-2014 and Doctoral studies 528-2011), PECET (University of Antioquia). 


\section{References}

Altschul, S.F., Madden, T.L., Schaffer, A.A., Zhang, J., Zhang, Z., Miller, W. \& Lipman, D.J. (1997) Gapped BLAST and PSIBLAST: A new generation of protein database search programs. Nucleic Acids Research, 25, 3389-3402. https://doi.org/10.1093/nar/25.17.3389

Arrivillaga, J.C., Navarro, J.C. \& Feliciangeli, D. (1999) Morfología y quetotaxia del tagma cefálico larval de Lutzomyia França, 1924 (Diptera: Psychodidae): Proposición de un sistema de nomenclatura. Boletín de Entomología Venezolana, 14, $1-13$.

Azpurua, J., De La Cruz, D., Valderrama, A. \& Windsor, D. (2010) Lutzomyia sand fly diversity and rates of infection by Wolbachia and an exotic Leishmania species on Barro Colorado Island, Panamá. Plos Neglected Tropical Diseases, 4, e627. https://doi.org/10.1371/journal.pntd.0000627

Bates, P.A., Depaquit, J., Galati, E.A., Kamhawi, S., Maroli, M., McDowell, M.A., Picado, A., Ready, P.D., Salomón, O.D., Shaw, J.J., Traub-Cseko, Y. \& Warburg, A. (2015) Recent advances in phlebotomine sand fly research related to leishmaniasis control. Parasites \& Vectors, 8, 131. https://doi.org/10.1186/s13071-015-0712-x

Blouin, M.S., Yowell, C.A., Courtney, C.H. \& Dame, J. (1998) Substitution bias, rapid saturation, and use of mtDNA for nematode systematics. Molecular Biology and Evolution, 15, 1719-1727. https://doi.org/10.1093/oxfordjournals.molbev.a025898

Boom, R., Sol, C.J., Salimans, M.M., Jansen, C.L., Wertheim, P.M. \& Noordaa, V.J. (1990) Rapid and simple method for purification of nucleic acids. Journal of Clinical Microbiology, 28, 495-503.

Cohnstaedt, L.W., Beati, L., Cáceres, A.G., Ferro, C. \& Munstermann, L.E. (2011) Phylogenetics of the phlebotomine sand fly group verrucarum (Diptera: Psychodidae: Lutzomyia). The American Journal of Tropical Medicine and Hygiene, 84, 913922. https://doi.org/10.4269/ajtmh.2011.11-0040

Contreras, M.A., Vivero, R.J. \& Uribe, S.I. (2013) DNA barcode: una herramienta para la identificación de Lutzomyia spp. a partir de larvas. Boletín Del Museo Entomológico Francisco Luís Gallego, 5, 7-16.

Contreras, M.A, Vivero, R.J., Vélez, I.D., Porter, C. \& Uribe, S.I. (2014) DNA Barcoding for the identification of sand fly species (Diptera, Psychodidae, Phlebotominae) in Colombia. PLoS ONE, 9, e85496. https://doi.org/10.1371/journal.pone.0085496

Depaquit, J. (2014) Molecular systematics applied to phlebotomine sandflies: review and perspectives. Infection, Genetics and Evolution, 28, 744-56. https://doi.org/10.1016/j.meegid.2014.10.027

Dvorak, V., Halada, P., Hlavackova, K., Dokianakis, E., Antoniou, M. \& Volf, P. (2014) Identification of phlebotomine sand flies (Diptera: Psychodidae) by matrix-assisted laser desorption/ionization time of flight mass spectrometry. Parasites \&Vectors, 7, 21. https://doi.org/10.1186/1756-3305-7-21

Endris, R.G., Young, D.G. \& Perkins, P.V. (1987) Ultrastructural comparison of egg surface morphology of five Lutzomyia species (Diptera: Psychodidae). Journal of Medical Entomology, 24, 412-415. https://doi.org/10.1093/jmedent/24.4.412

Fausto, A.M, Feliciangeli, M.D, Maroli, M. \& Mazzini, M. (1998) Ootaxonomic investigation of five Lutzomyia species (Diptera, Psychodidae) from Venezuela. Memórias do Instituto Oswaldo Cruz, 96, 197-204.

Feliciangeli, M.D., Castejón, O.C. \& Limongi, J. (1993) Egg surface ultrastructure of eight New World phlebotomine sand fly species (Diptera: Psychodidae). Journal of Medical Entomology, 30, 651-656. https://doi.org/10.1093/jmedent/30.4.651

Feliciangeli, M.D. (2004) Natural breeding places of phlebotomine sandflies. Medical and Veterinary Entomology, 18, 71-80. https://doi.org/10.1111/j.0269-283X.2004.0487.x

Folmer, O., Black, M., Hoeh, W., Lutz, R. \& Vrijenhoek, R. (1994) DNA primers for amplification of mitochondrial cytochrome c oxidase subunit I from diverse metazoan invertebrates. Molecular marine biology and biotechnology, 3, 294-299.

Hanson, W.J. (1968) The breeding places of Phlebotomus in Panamá (Diptera: Psychodidae). Annals of the Entomological Society of America, 54, 317-322. https://doi.org/10.1093/aesa/54.3.317

Hall, T.A. (1999) BioEdit: a user-friendly biological sequence alignment editor and analysis program for Windows 95/98/NT. Nucleics Acids Symposium Series, 41, 95-98. https://doi.org/10.1021/bk-1999-0734.ch008

Hebert, P.D., Cywinska, A., Ball, S.L. \& Dewaard, J.R. (2003) Biological identifications through DNA barcodes. Proceedings of the Royal Society of London, 270, 313-321. ttps://doi.org/10.1098/rspb.2002.2218

Higgins, D.G., Bleasby, A.J. \& Fuchs, R. (1992) CLUSTAL V: improved software for multiple sequence alignment. Computer Applications in the Biosciences, 8, 189-191. 
https://doi.org/10.1093/bioinformatics/8.2.189

Kato, H., Cáceres, A.G., Gómez, E.A., Mimori, T., Uezato, H. \& Hashiguchi, Y. (2015) Genetic divergence in populations of Lutzomyia ayacuchensis, a vector of Andean-type cutaneous leishmaniasis, in Ecuador and Peru. Acta Tropica, 141, 7987. https://doi.org/10.1016/j.actatropica.2014.10.004

Kimura, M. (1980) A simple method for estimating evolutionary rate of base substitutions through comparative studies of nucleotide sequences. Journal of Molecular Evolution, 16, 111-120. https://doi.org/10.1007/BF01731581

Lanteri, A. (2007) Código de barras del ADN y sus posibles aplicaciones en el campo de la Entomología. Revista Sociedad Entomologica Argentina, 66, 15-25.

Miller, L.J., Graham, Allsopp, P.G. \& Yeates, D.K. (1999) Identification of morphologically similar canegrubs (Coleoptera: Scarabaeidae: Melolonthini) using a molecular diagnostic technique. Australian Journal of Entomology, 38, 189-196, https://doi.org/10.1046/j.1440-6055.1999.00110.x

Miller, K.B., Alarie, Y., Wolfe, W.G. \& Whiting, M.F. (2005) Association of insect life stages using DNA sequences: the larvae of Philodytes umbrinus (Motschulsky) (Coleoptera: Dytiscidae). Systematic Entomology, 30, 499-509. https://doi.org/10.1111/j.1365-3113.2005.00320.x

Nzelu, C.O, Cáceres, A.G., Arrunátegui-Jiménez, M.J., Lañas-Rosas, M.F., Yañez-Trujillano, H.H., Luna, D.V., Holguín C.E., Katakura, K., Hashiguchi, Y. \& Kato, H. (2015) DNA barcoding for identification of sand fly species (Diptera: Psychodidae) from leishmaniasis-endemic areas of Peru. Acta Tropica, 145, 45-51. https://doi.org/10.1016/j.actatropica.2015.02.003

Paquin, P. \& Hedin, M. (2004) The power and perils of 'molecular taxonomy: a case study of eyeless and endangered Cicurina (Araneae: Dictynidae) from Texas caves. Molecular Ecology, 13, 3239-3255. https://doi.org/10.1111/j.1365-294X.2004.02296.x

Pérez, J. \& Ogusuku, E. (1997) Chorion patterns on eggs of Lutzomyia sandflies from the Peruvian Andes. Medical and Veterinary Entomology, 11, 127-33.

https://doi.org/10.1111/j.1365-2915.1997.tb00301.x

Pinto, I.S., Chagas, B.D., Fuzari, A.A., Ferreira, A.L., Rezende, H.R., Bruno, R.V., Falqueto, A., Andrade-Filho, J.D., Galati, E.A., Fernandes, P.H., Brazil, R.P. \& Peixoto, A.A. (2015) DNA Barcoding of Neotropical Sand Flies (Diptera, Psychodidae, Phlebotominae): Species Identification and Discovery within Brazil. PLoS ONE, 10 (10), e0140636. https://doi.org/10.1371/journal.pone.0140636

Romero, R., Lastre, L., Pérez-Doria, A. \& Bejarano, E. (2016) DNA barcoding to identify species of phlebotomine sand fly (Diptera: Psychodidae) in the mixed leishmaniasis focus of the Colombian Caribbean. Acta Tropica, 159, pp. $125-131$. https://doi.org/10.1016/j.actatropica.2016.03.017

Saitou, N. \& Nei, M. (1987) The neighbor-joining method: A new method for reconstructing phylogenetic trees. Molecular Biology and Evolution, 4, 406-425.

Sierra, A.D., Vélez, I.D. \& Uribe, S.I (2000) Identificación de Lutzomyia spp. (Diptera: Psychodidae) grupo verrucarum por medio de microscopia electrónica de sus huevos. Revista de Biología Tropical, 48, 615-622.

Tamura, K., Peterson, D., Peterson, N., Stecher, G., Nei, M. \& Kumar, S. (2011) MEGA 5: Molecular Evolutionary Genetics Analysis using Maximum Likelihood, Evolutionary Distance, and Maximum Parsimony Methods. Molecular Biology and Evolution, 28, 2731-2739. https://doi.org/10.1093/molbev/msr121

Vivero, R.J., Bejarano, E.E. \& Contreras, M.A. (2007) Análisis de la estructura primaria y secundaria del ARN de transferencia mitocondrial para Serina en siete especies de Lutzomyia. Biomédica, 27, 429-438. https://doi.org/10.7705/biomedica.v27i3.205

Vivero, R.J, Ortega-Gómez, E., Aparicio, Y., Torres-Gutierez, C., Muskus, C. \& Bejarano, E.E. (2013) Adult and immature Phlebotomine sandflies (Diptera: Psychodidae): records for the Caribbean region of Colombia. Boletín de Malariología y Salud Ambiental, 3, 1-10.

Vivero, R.J., Torres-Gutierrez, C., Bejarano, E.E., Cadena-Peña, H., Estrada, L.G., Flórez, F., Ortega, E., Aparicio, Y. \& Muskus, C. (2015) Study on natural breeding sites of sand flies (Diptera: Phlebotominae) in areas of Leishmania transmission in Colombia. Parasites and Vectors, 8, 116. https://doi.org/10.1186/s13071-015-0711-y

Ward, D. (1976) A revised numerical chaetotaxy for neotropical Phlebotomine sandfly larvae (Diptera: Psychodidae). Systematic Entomology, 1, 89-94.

https://doi.org/10.1111/j.1365-3113.1976.tb00035.x 